\title{
ESTIMATING POLLUTANT REMOVAL REQUIREMENTS FOR LANDFILLS IN THE UK: III. POLICY ANALYSIS AND OPERATIONAL IMPLICATIONS
}

\author{
D. H. Hall ${ }^{1}$, D. Drury ${ }^{1}$, J. R. Gronow ${ }^{2}$, S. J. T. Pollard ${ }^{2}$ and R. Smith²*
}

\author{
${ }^{1}$ Golder Associates (UK) Ltd., Attenborough House, Browns Lane Business Park, Stanton-on-the- \\ Wolds, NG12 5BL, UK \\ 2 Integrated Waste Management Centre, Sustainable Systems Department, School of Applied \\ Sciences, Cranfield University, MK43 0AL, UK \\ * Corresponding author Tel +44 (0)1234 754963; Fax +44 (0)1234 376171; e-mail \\ r.smith1@cranfield.ac.uk
}

\begin{abstract}
The policy analysis and management implications for achieving landfill equilibrium status within a sustainable timescale (decades rather than centuries) are presented based on modelled results reported previously. Until relatively recently, timescale estimates suggested that equilibrium or landfill completion could be achieved within 40-60 years i.e. the same order of magnitude as financial provision for aftercare. However results of modelling in this study (reported in previous paper) suggest that timescales may be considerably longer (many centuries in some instances) suggesting that financial provision may be inadequate. The role of the most promising and available waste treatment technologies and strategic waste management options in contributing towards achieving equilibrium status are discussed. Results suggest that a re-examination of
\end{abstract}


techniques for accelerating landfill stabilisation, including aerobic and bioreactor landfill, is warranted.

Keywords: Equilibrium; completion; emissions; MSW

\section{INTRODUCTION}

This work presents the final part of a series of three companion papers. The first manuscript presented a benchmark study of leachate modelling and reviewed treatment technologies likely to form the basis of meeting the biodegradable municipal waste diversion targets of the Landfill Directive [1] in England and Wales. The second manuscript presented model development [2]. Landfill pollutant removal is intrinsically linked with achieving environmental equilibrium status. Equilibrium is defined here as that state when emissions from a landfill site occur at a rate that allows sufficient natural attenuation in the surrounding environment to prevent environmental harm, so management is no longer required. To embody the principles of sustainability, equilibrium can only be achieved when the management period (post-closure when the site has ceased accepting waste for disposal) is measured in decades rather than centuries. Landfills must remain under management control until the surrender of a landfill permit or licence is accepted by the regulator. Surrender is a site-specific determination and it can only be accepted if a landfill has stabilised physically, chemically and biologically to such a degree that the undisturbed contents of the site are unlikely to pose a pollution risk in the landfill's environmental setting (landfill completion) [3].

\section{POLICY AND OPERATIONAL IMPLICATIONS}




\section{Sustainable Landfill}

Large-scale modern engineered landfill sites, developed for groundwater protection, are now a common aspect of the waste management system in many countries. Despite this, they are comparatively new, with their development only starting in the 1980s. Consequently such sites, that predominantly contain untreated wastes, are a long way from achieving landfill completion or equilibrium status. One measure of landfill sustainability, an aspect that the EU Landfill Directive [4] does not explicitly consider, is the timescale required to achieve landfill equilibrium. Consideration of landfill sustainability requires an understanding of complex landfill processes that are responsible for stabilisation. There are two main methods of achieving sustainable landfill; flushing in situ wastes or pre-treating waste to produce residues that meet set criteria prior to disposal. Current pre-treatment techniques do not produce residues capable of meeting stabilisation criteria [5].

Site-specific landfill leachate measurements provide some indication of landfill processes, but recent modelling is starting to provide an understanding of the factors that control leachate quality [6]. An increased understanding of waste streams that disproportionately affect leachate quality may suggest a change in management practice is required (e.g. waste segregation, diversion, development of additional pre-treatment techniques) so as to bring forward the achievement of equilibrium. This could ultimately increase the sustainability of landfill.

\section{Strategic Waste Management Options}


Whilst raw municipal solid wastes (MSW) managed within a site allowing a moderate amount of leachate flushing, may be close to achieving equilibrium status, the requirements of the Landfill Directive [4] will make this option unavailable for the majority of sites as pre-treatment is a prerequisite of the Directive. This result is contrary to predictions made in the early 1990s [7-9] when it was recognised that measures have to be taken to enhance landfill degradation processes else degradation was likely to take many centuries for landfills to meet trigger concentrations. Combusting raw MSW in incinerators will meet the waste diversion targets, but the effect of combustion and the concentration of non-combustible fractions would appear to make equilibrium status more difficult to achieve. Processing of ash (either artificially or naturally via carbonation) reduces the level of emissions of some heavy metals such as lead and zinc, but results in a significant increase in the sulphate emission.

Coupled with the problems of landfilling the ash, there is the issue of the disposal of air pollution control (APC) wastes and fly ash which may be classified as hazardous wastes. It is unlikely that APC waste from the majority of incinerators will meet the current hazardous waste acceptance criteria (WAC), and an additional waste pre-treatment will be needed for these wastes (or an alternate means of disposing of them needs to be found).

Treatment technologies such as mechanical biological treatment (MBT) followed by intensive composting may provide a means of getting close to the objectives. However, the hydraulic conductivity of MBT residues may make it difficult to recirculate the fluids or introduce irrigation within the landfill, meaning that they will remain at low liquid/solid (L/S) ratios for extended periods. This technology does also remain highly dependent upon the feed stock 
entering the process, and there is little experience in the UK in managing variations in plant feed stock.

Results of this study (not reported here) supported the notion that it is leachate and not landfill gas (LFG) that will be the rate limiting process for achieving equilibrium status. In all cases the LFG emissions fell below a manageable production rate prior to leachate reaching the requirements of equilibrium status. In some cases this was marginal but in such scenarios, the management option that best suited the requirements of rapid stabilisation included moderate flushing of the landfill to wash leachable contaminants from the landfill and at the same time optimise the rate of gas generation (in order to degrade the organic carbon as soon as possible).

\section{Flushing of Wastes}

The waste management industry has discussed the concept of the flushing bioreactor for many years, and the majority of practitioners believe that it is fundamentally workable provided there are large volumes of water available. Flushing rates in excess of $2000 \mathrm{~mm} \mathrm{y}^{-1}$ of equivalent infiltration have been reported [10] and such rates may be needed to achieve stabilisation (but perhaps not be achievable) for landfills in excess of $50 \mathrm{~m}$ deep. Some hydraulic properties of waste change dramatically with depth [11]. The scenarios that we examined here concentrated on relatively thin waste deposits (circa $20 \mathrm{~m}$ ) but with considerably lower flushing rates. The modelling assumed that during the operational period there is infiltration of $250 \mathrm{~mm} \mathrm{y}^{-1} \mathrm{from}$ rainfall, falling to $50 \mathrm{~mm} \mathrm{y}^{-1}$ upon capping of the site. For the flushing scenarios, there is an assumed further addition of $200 \mathrm{~mm} \mathrm{y}^{-1}$ for the MBT, raw MSW and one of the stable non-reactive 
hazardous waste options, and $500 \mathrm{~mm} \mathrm{y}^{-1}$ for mechanically sorted organic residues (MSOR), incinerator bottom ash (IBA) and the other stable non-reactive hazardous wastes scenarios during the period of active management. The choice was dictated in part by the results of the non-flushed model results for each waste residue. There was an assumption that if the liquid being recirculated is leachate (rather than water) it should have undergone at least some basic treatment to remove high concentrations of organics and ammoniacal nitrogen. Sulphate and chloride removal would not normally be an issue for raw MSW or MBT residues as these leachates would be unlikely to reach solubility limits for these species, but could do so if concentrations were allowed to build up. The reality is that additional infiltration of the order of $200 \mathrm{~mm} \mathrm{y}^{-1}$ would be readily achievable from run-off available from capped areas for the majority of sites in the UK. Additional infiltration amounting to $500 \mathrm{~mm} \mathrm{y}^{-1}$ would be geographically more restrictive. Flushing as a means of accelerating the stabilisation of landfilled waste has been advocated for many years [10] and research continues to demonstrate that it can serve to shorten the aftercare period considerably. However, there is no real incentive for the waste industry to invest in such practice. It seems that the recent revision of financial provisions was a missed opportunity to provide that incentive. It might have been possible to introduce a two or three tiered system with lower amounts of money set aside at sites where accelerated stabilisation measures were installed.

In the case of IBA landfills, the leachate would be quite different from that found in the more organic sites that we are familiar with. Leachates from these landfills will be largely inorganic and contain primarily metal salts. Alternate leachate treatment technologies will be required and the recirculation of treated leachate could be more problematic since the removal of sulphate will be needed to avoid saturation of these salts. 
In many respects, the easiest way to achieve higher flushing rates would be to postpone the installation of a cap until equilibrium status was achieved. However, for wastes that are likely to require any form of landfill gas control, such an option is not viable. It may be an option for incinerator bottom ash (IBA) wastes as there is little evidence that the ash generates landfill gas, and odour should not be an issue. This might be a function of the site geometry as a deeper landfill will require a larger degree of flushing or a longer management time to achieve the required L/S ratio, but the depth of the site is unlikely to have a pronounced affect on the gas generation rate and the time to reach equilibrium status in respect of gas. The option of removing a cap at the end of the gassing phase of a landfill may remain, subject to the regulatory requirements for minimisation of leachate production.

Removal of the cap at this stage would be similar to maintaining a flushing rate at $250 \mathrm{~mm}$ $\mathrm{y}^{-1}$ and could then proceed as a flushed site for a further 40 years or so, at which time it would achieve equilibrium status. Thus, this management scenario would not require re-circulation of leachate, nor would it require collection and injection of water specifically to achieve the flushing rates. The resultant time to equilibrium status would be extended by around 30 years, but would be significantly shorter than if the cap were to remain in place.

Furthermore, the liner performance can be expected to be better during the first century of its operation as the degradation due to loss of antioxidants is unlikely to occur within this period [12]. One issue that would make this option less favourable is the disturbance of what would have been a restored landform for some 30 years or so. 
The time disjoint between achieving what is modelled as equilibrium status and the maximum groundwater impact probably remains one of the major obstacles to the practical use of this work. It will require pragmatic regulation in order to issue a closure certificate for a landfill that still contains contaminants at 10 times the water quality standard. This could be further compounded by the fact that most waste permits will require a specific leachate head to be maintained. In order to approach the sort of conditions that might occur when equilibrium status is approached, there may need to be a planned gradual increase in leachate level so that the site reaches some degree of hydraulic equilibrium as well as chemical equilibrium with its surroundings.

\section{Leachate Strength at Equilibrium Status}

It was envisaged that the research would indicate a leachate strength at which equilibrium status could be shown to have been achieved and, along with other tests and monitoring data, allow a completion certificate to be issued for a site. The work undertaken here showed that the relationship between leachate strength and equilibrium status is far from linear. Where a site meets our definition of equilibrium early on, then the concentrations of leachate within the site that satisfy equilibrium will be higher than where the site meets the requirements later. This is simply a function of the degradation of the liner and capping systems where there is an expectation that these systems will see degradation with advancing age. This is compounded by the fact that those sites that will need an extended aftercare period will also have to continue to manage leachate to a quality that is less polluting than one where the aftercare period is shortened due to selective processing or flushing. 
It has been suggested that the Inert $\mathrm{WAC}_{0}$ values (initial eluate from the percolation test prCEN/TS 14405:2003) for inert waste sites might have shown an indication of the leachate quality at the point of equilibrium. It was therefore worth comparing the typical ranges obtained from this study (albeit that they varied due to time dependency issues) with the WAC values for inert waste landfills. A comparison of the leachate concentrations and the inert $\mathrm{C}_{0}$ values is shown in Table 1.

These results indicated that while there is a generalised relationship between the formal $\mathrm{C}_{0}$ values for inert wastes and those derived from this study, the relationship is not always strong enough to be relied upon. This conclusion follows that of the time dependency issue; although there are a number of cases where the leachate concentrations need to fall well below the inert $\mathrm{WAC}_{0}$ values for inert waste sites (e.g. copper, lead and chloride). This is in part due to the way in which the $C_{0}$ values were generated, being a combination of modelling, rounding up/down and a comparison with leach test data from common waste streams that are deemed to be inert.

\section{Ammoniacal Nitrogen}

It is clear that certain species drive the time periods required to achieve equilibrium status. Prior to this research it was thought that ammoniacal nitrogen would be a governing factor given its high concentration in raw MSW leachates and low environmental threshold. While the modelling undertaken did not indicate that ammoniacal nitrogen was a major problem, it is recognised that some MSW leachates contain considerably more ammoniacal nitrogen than those 
modelled. It is of some comfort that the MBT compost process removes a large amount of ammoniacal nitrogen and fixes the organic nitrogen in other less mobile forms.

While this is to an extent reassuring, there remain a significant number of current landfills within the UK where ammoniacal nitrogen will continue to be a notable issue for many years. In addition, the modelling in this study assumed a composite liner. Where clay liners are used, it is likely that a greater flux of ammoniacal nitrogen will result and that this may still be an issue that affects the attainment of equilibrium status. What is surprising is the lack of commercial development of the research that has shown benefits associated with the injection of nitrified leachate back into the waste mass. Work by Burton and Watson-Craik [13] has shown that the introduction of nitrate into waste results in the denitrification of the leachate (resulting in the formation of nitrogen gas) and a substantial reduction in the nitrogen load within the landfill.

Ammoniacal nitrogen is likely to be much more of a consideration with regard to surface waters in instances where specific landfill sites are at risk of spilling over (the bathtub effect). This can occur as a result of continued integrity of containment coupled with the waste being saturated. Our modelling thus far not included emissions to surface water, which could form a separate study.

\section{Accelerating the Achievement of Equilibrium: Air Injection}

In a similar vein work has been undertaken, particularly in Germany and Italy, relating to the injection of compressed air into landfills that are in their methanogenic stage. Conventional landfill disposal encourages waste decomposition processes that operate anaerobically. This study 
has reported that modelled predictions suggest that landfill completion may take centuries, based on modern highly engineered landfills. This raises the question of sustainability for both operational landfills and the landfill legacy i.e. sites that are no longer licensed or permitted, some of which pre-date regulation. Many of these latter sites are ex-local authority landfills that are often relatively shallow and are slowly degrading with considerable pollution potential remaining. This treatment affords an opportunity to accelerate the stabilisation process for organic waste aerobically and potentially return sites to market for redevelopment in a timely fashion.

Whilst the benefits of aerobic or semi-aerobic landfill have been clearly demonstrated, including full-scale studies in Spain and Canada, many practitioners are sceptical of the benefits and are concerned about the risks such as gaseous emissions and entry of oxygen into a landfill that could cause fires. Other uncertainty surrounds the optimum point at which to begin aeration and the effect of aeration on leachate parameters.

Cossu et al. [14] reported the full scale stabilisation of part of a landfill (for rail construction purposes) by the injection of compressed air over a 140 day period. A marked drop in methane generation occurred and presumably an aerobic composting process was established. The study did not report the affects on the leachate quality during this period, but it would be expected that there would be a reduction in ammoniacal nitrogen production and a fall in BOD and COD, accompanied by a reduction in TOC levels. Work by Purcell and Walker [15] showed that on a pilot scale, the forced aeration of green waste and shredded biodegradable MSW can achieve a relatively stable residue within 6 months (aerox process). While the organic indicators (BOD, COD and $\mathrm{NH}_{4}$ ) all showed marked reductions from the control cells, unsurprisingly the total heavy metal content of the waste remained virtually unaffected. The removal of some of the organic 
material will result in a long-term lowering of the TOC content of the waste and a subsequent reduction in the capacity to generate organo-metal complexes that form readily with some metals (especially copper).

While the aerox process was designed primarily as a means of pre-treatment of organic wastes, the work by Cossu [14] showed that it is feasible to undertake forced aeration in situ on a landfill site scale. It may therefore be possible to speed up the stabilisation of wastes that are approaching the end of their methanogenic life and achieve equilibrium status at least for landfill gas. Certainly the application of forced air injection either at the beginning or the end of the landfilling process would remove certain trace organic species that remain problematical within biologically active landfills and pose a threat to groundwater quality. While a number of researchers are looking at this area of forced aeration of organic wastes, rate constants still remain to be generated so that these processes can be readily modelled and the effects predicted.

\section{Controlling Inorganic Species}

Depending upon the waste treatment and the applied technologies, different inorganic species appear to control the time taken to achieve equilibrium status. For conventional raw MSW, these are likely to be lead and chloride (with ammoniacal nitrogen at sites where biodegradation in the groundwater is unlikely, or above average concentrations exist). For MBT residues, these include lead, nickel, zinc, sulphate and chloride (but not ammoniacal nitrogen). For IBA the contaminants most likely to cause problems are antimony, cadmium, copper, molybdenum, zinc 
and chloride. As the ash undergoes carbonation, zinc and lead will cease to be an issue but will be replaced by sulphate.

Certain MSW waste streams contain high proportions of these contaminants and it might be worth considering whether the likely changes in waste management practices could result in an increased diversion of these waste streams from landfill. In the case of energy from waste mass burn (EfWMB), much of the organic and combustible fraction of the waste will be lost from the waste mass (primarily carbon in its many forms) although any metals in these fractions may well be retained. It is only when certain waste fractions are removed from a waste stream (as might happen in the sorting and mechanical treatment stage of MBT) that whole waste fractions will be removed from the final residue. Contaminants within the waste entering an EfWMB will be partitioned between the IBA and the APC and fly ash generated. Given the concentrating effects of combustion (in relation to non-combustible fractions) and the change in oxidation state that results in some metals becoming more leachable, it is not entirely surprising that IBA performs least well in the modelling undertaken.

Table 2 contains the percentage proportions of a selection of elemental contaminants in raw MSW. The figures take into account the composition of the waste fraction itself, and the relative proportion of that fraction within a typical household waste stream. It does not take into account the relative leachability of the contaminants from each waste fraction nor does it consider any changes to the leachability through waste treatment or combustion. However, Table 2 could be useful as a guide for managing a specific site e.g. if cadmium is a concern, removal of the dense plastic waste stream could be a priority. 
For MBT residues, we might expect that many of the contaminants associated with paper, plastics, ferrous and non-ferrous metals, and Waste Electrical \& Electronic (WEE) goods will be removed. Given that for MBT issues remain with lead, nickel and zinc, it is of some concern that these elements are predominantly present within waste streams that should have been largely removed. With respect to lead, nearly 50\% of the total lead in MSW should have been removed. For nickel the removal figure is 53\%, and for zinc the figure is nearly $45 \%$ (see Table 2). Part of the reason why these contaminants remain a problem could be that much of the research on MBT residues comes from continental Europe, while the compositional data from MSW has been derived solely from UK waste streams. In addition, it must be remembered that MBT residues are likely to have a higher density than raw MSW and hence will contain a higher contaminant load within the same landfill volume. The fact that intensively composted MBT residues appear to have lower leachable metal content than less intensively composted MBT is not something that is readily understood, and may imply a fundamental difference in the overall performance of different MBT plants.

\section{Organic Species}

The understanding of the origins of some of the trace organics within leachate (which have not been modelled in this study) and landfill gas remains poor for many species. Certain trace organics such as mecoprop that is present in nearly all MSW landfills is probably one of the best understood, and is thought to originate from green waste (grass cuttings) and empty (or partially empty) herbicide containers. Mecoprop along with a number of other organic species appears 
routinely in leachate samples primarily because they do not degrade anaerobically; and they are not volatile and hence do not partition into the landfill gas phase.

There is a very clear advantage in subjecting these contaminants (in the waste that they exist in) to an aerobic degradation period prior to placing them in to a landfill. Other contaminants, such as heavily chlorinated solvents, will degrade only in anaerobic conditions. However, these groups of compounds tend to be more volatile and will partition into the landfill gas phase.

\section{Measuring Equilibrium Status}

One of the objectives of this work was to define a method for assessing when a site can be regarded as having achieved equilibrium status. This research has shown that this is a complex issue and one that will, in part, be based on the specific design of a landfill and upon its local hydrogeological regime. Furthermore, the criteria used to judge the impact on groundwater will almost certainly not be the Drinking Water Standard (DWS) that has been used for the comparative modelling that has been reported in this document. Under the Water Framework Directive [16] it is likely that groundwater quality criteria will be developed for specific groundwater bodies or classes of groundwater body. Furthermore, the revised Groundwater Directive [17] may include a change in the way the discharge of Listed substances is regulated. These may change the way completion will be judged and may have a marked impact on the completion time or equilibrium status of a landfill. 
Leachate quality and an assessment of the hydraulic performance of a site, coupled with long-term monitoring data from the site remains the only viable means of assessing completion criteria at present. This will have to be addressed on a site-specific basis as it is clear that no uniform standard will work in each and every case.

For sites where flushing has been undertaken over the entire landfill area it is likely that much of the waste will have achieved a reasonably high L/S ratio, and while there are bound to be areas that have (due to short circuiting) received less flushing than others, on the whole, the residual emissions are likely to be acceptable. For sites where there has been less flushing, or flushing is restricted to certain areas of the site, then an investigation of the leaching properties of the waste may be warranted. The leach tests defined for the WAC characterisation testing will be appropriate tests, and the degree of variance between samples and comparison between the leach test data and existing leachate quality will provide an indication as to whether the whole site has reached equilibrium status or whether water flow through the waste has been channelled in very specific areas.

The fact remains that it is easy to measure leachate concentrations. What is needed is a means of measuring the flux of contaminants migrating from the site. Only when we are in a position to measure the flux can we properly judge the equilibrium status in a way that does not require a great deal of conservatism. 


\section{CONCLUSIONS}

This study has examined the municipal solid waste streams that the UK will most probably generate following the implementation of the Landfill Directive requirements to reduce biodegradable waste from going to landfill and the requirements for waste pre-treatment. The properties of the residues undergoing the most likely processes were investigated via a literature search and an assessment made via modelling of the probable management times these residues would require within a landfill environment. A re-evaluation of these properties in light of emerging knowledge, for example on pre-treatment aspects, may show whether such aspects bring us any closer to equilibrium status or further from it.

Each process investigated generates a residue that will need to be landfilled and there is a likelihood that at times the products generated by these processes (e.g. MBT compost, or refuse derived fuel (RDF) material) may be out of specification, or in quantities greater than the demand, and hence these may also need to be landfilled.

On the whole those processes that involve the combustion of wastes are shown to lengthen the period of time taken for the landfill to reach equilibrium status. This is partially due to the higher densities of the wastes resulting from combustion and hence the higher amount of metals and salts that can be disposed off within the same landfill void space. However, the same argument cannot be applied to intensively composted MBT residues which, despite their higher density, give the best performance waste residues considered. Interestingly, these MBT residues that result from intense composting perform as well as, but no better than, raw MSW except that 
they give the same performance while possessing a higher density, and therefore represent a better use of the void space within a landfill.

Leaching processes can be accelerated by the flushing of landfills with either recirculated, but treated, leachate, or the infiltration of additional volumes of water. Other processes that show promising results at full scale were discussed, including landfill aeration and recirculation with nitrified leachate.

The modelling was restricted to those processes that are readily modelled (even if the model parameters are uncertain). There remain a number of landfill processes and management practices (such as nitrate injection and air injection) that are the subject of interest world-wide but as yet have not been developed to the extent that the processes have rate constants. Air injection in particular, shows promising results in reducing the emissions from landfill with marked improvement in leachate quality. It is likely that modelling the effectiveness of these processes will be forthcoming in the very near future. Further work is required to examine more critically the sensitivity to baseline assumptions, such as $C_{0}$, hydrogeological settings and kappa values. This can only happen once more data values are available.

While this study does not provide the answers to how the landfill aftercare period may be shortened sufficiently to attain sustainable development criteria i.e. achieving equilibrium within decades rather than centuries, it does take a step in the right direction and identifies where significant progress can be made towards achieving sustainable landfill and equilibrium status. It is clear that until such time as landfill sites achieves this status, risk assessment will be required. A sensitivity analysis of the baseline assumptions and data underpinning the modelling work is 
required. This was beyond the scope of our study but it could lead to the development of equilibrium criteria. A full technical and economic reappraisal of techniques that demonstrably accelerate waste decomposition processes is justified on the basis of modelled results presented in this study.

\section{ACKNOWLEDGEMENTS}

The modelling work on which this paper is built was jointly funded by the Environment Agency for England and Wales and ESART. This paper is published with permission. Opinions expressed are the authors' alone.

\section{REFERENCES}

1. Hall D.H., Drury D., Gronow J.R., Rosevear A., Pollard S.J.T. and Smith R., Estimating pollutant removal requirements for landfills in the UK: I. Benchmark study and characteristics of waste treatment technologies. Environmental Technology, Submitted (2006).

2. Hall D.H., Drury D., Gronow J.R., Rosevear A., Pollard S.J.T. and Smith R., Estimating pollutant removal requirements for landfills in the UK: II. Model development. Environmental Technology, Submitted (2006).

3. Environment Agency, Guidance on landfill completion: a consultation by the Environment Agency. Environment Agency, Bristol (2003).

4. Council of the European Union, Directive 1999/31/EC on the Landfill of Waste. Official Journal of the European Communities, L 182, 1-19 (1999).

5. Knox K., Sustainable landfill in the UK: a review of current knowledge and outstanding R\&D needs. Report to ESART, London, 38pp (2000).

6. $\quad$ van der Sloot H.A., End of black box approach? A step towards more sustainable landfills. Waste Management, 25, 461 (2005).

7. Harris R.C., Knox K. and Walker N., Anticipating developments in landfill design and operation. In: Proc. Landfill tomorrow - bioreactors or storage, Imperial College, Centre for Environmental Control \& Waste Management, pp. 25-35 (1993).

8. Knox K., The relationship between leachate and gas. In: Landfill Gas: Energy and Environment '90, Richards G.E. and Alston Y.R. (eds.), Harwell Laboratories, Bournemouth, pp. 367-386 (1990).

9. $\quad$ Stegmann R., Concepts of waste landfilling. In: Proc. Sardinia '95, 5th International Landfill Symposium, Cagliari, Sardinia, pp. 3-12 (1995).

10. Institute of Wastes Management, The role and operation of the flushing bioreactor. IWM Sustainable Landfill Working Group, Northampton, (1999). 
11. Beaven R.P. and Powrie W., Determination of the hydrogeological and geotechnical properties of refuse using a large scale compression cell. In: Proc. Sardinia '95, Fifth International Landfill Symposium, Cagliari, Italy, pp. 745-760 (1995).

12. Needham A., Gallagher E., Peggs I., Howe G. and Norris J., The likely medium to long-term generation of defects in geomembrane liners. R\&D Technical Report P1-500/1/TR. Environment Agency, Bristol, (2004).

13. Burton S.A.Q. and Watson-Craik I.A., Accelerated landfill refuse decomposition by recirculation of nitrified leachate. In: Proc. Sardinia 1999: Seventh International Waste Management and Landfill Symposium, Cagliari, pp. 119-126 (1999).

14. Cossu R., Raga R. and Rossetti D., Full scale application of in situ aerobic stabilization of old landfills. In: Proceedings Sardinia 2003, Ninth International Waste Management and Landfill Symposium, S. Margherita di Pula, Cagliari, Italy (2003).

15. Purcell B.E. and Walker N., Further demonstrations of aerox waste treatment. In: Waste 2004 Integrated Waste Management and Pollution Control: Policy and Practice, Research and Solutions, Stratford-upon-Avon, UK, pp. 13-21 (2004).

16. European Parliament and European Council, Directive 2000/60/EC of the European Parliament and of the Council of 23 October 2000 establishing a framework for Community action in the field of water policy (Water Framework Directive). Official Journal L 327, 22/12/2000, 1-72 (2000).

17. Commission of the European Communities, Proposal for a Directive of the European Parliament and of the Council on the protection of groundwater against pollution. COM(2003) 550 final, Brussels (2003).

18. Department of Environment, UK National Household Waste Analysis Programme, technical report, phase 1. Research Report CWM 044/93, Environment Agency, Bristol (1993). 


\section{TABLE TITLE LIST}

Table 1. Comparison of inert $\mathrm{WAC} \mathrm{C}_{0}$ values and leachate concentrations at equilibrium status.

Table 2. Percentage distribution of specific elements in waste fractions. 
Table 1. Comparison of inert $\mathrm{WAC}_{0}$ values and leachate concentrations at equilibrium status.

\begin{tabular}{|c|c|c|c|c|}
\hline Component & $\begin{array}{l}\text { Raw } \\
\text { MSW } \\
\text { mg l-1 }^{-1}\end{array}$ & $\begin{array}{l}\text { MBT \& } \\
\text { MSOR } \\
\text { mg l-1 }^{-1}\end{array}$ & $\begin{array}{l}\text { Incinerator } \\
\text { bottom } \\
\text { ash } \\
\mathrm{mg} \mathrm{l}^{-1}\end{array}$ & $\begin{array}{c}\mathrm{C}_{0} \text { (percolation test) from } \\
\text { inert WAC } \\
\mathrm{mg} \mathrm{l}^{-1}\end{array}$ \\
\hline As & 0.03 & $\mathrm{n} / \mathrm{a}$ & $\mathrm{n} / \mathrm{a}$ & 0.06 \\
\hline $\mathrm{Ba}$ & $\mathrm{n} / \mathrm{a}$ & $\mathrm{n} / \mathrm{a}$ & $\mathrm{n} / \mathrm{a}$ & 4 \\
\hline $\mathrm{Cd}$ & 0.01 & 0.018 & 0.008 & 0.02 \\
\hline $\mathrm{Cr}$ & 0.8 & 0.8 & $\mathrm{n} / \mathrm{a}$ & 0.1 \\
\hline $\mathrm{Cu}$ & 0.25 & 0.4 & 0.2 & 0.6 \\
\hline $\mathrm{Hg}$ & 0.002 & $\mathrm{n} / \mathrm{a}$ & $\mathrm{n} / \mathrm{a}$ & 0.002 \\
\hline Mo & 0.3 & $\mathrm{n} / \mathrm{a}$ & 0.2 & 0.2 \\
\hline $\mathrm{Ni}$ & $0.2-2.5$ & 0.25 & $\mathrm{n} / \mathrm{a}$ & 0.1 \\
\hline $\mathrm{Pb}$ & $\begin{array}{l}0.08- \\
0.13\end{array}$ & 0.13 & 0.03 & 0.15 \\
\hline $\mathrm{Sb}$ & $\begin{array}{c}0.008- \\
0.01\end{array}$ & $\mathrm{n} / \mathrm{a}$ & 0.01 & 0.01 \\
\hline Se & $\begin{array}{l}0.03- \\
0.04\end{array}$ & $\mathrm{n} / \mathrm{a}$ & $\mathrm{n} / \mathrm{a}$ & 0.04 \\
\hline $\mathrm{Zn}$ & $0.75-0.8$ & 0.8 & $\mathrm{n} / \mathrm{a}$ & 1.2 \\
\hline Chloride & $960-1230$ & $430-1480$ & $720-980$ & 450 \\
\hline Fluoride & $3.5-5.4$ & $\mathrm{n} / \mathrm{a}$ & $\mathrm{n} / \mathrm{a}$ & 2.5 \\
\hline Sulphate & 860 & $400-1100$ & $350-1050$ & 1500 \\
\hline $\mathrm{NH}_{4}$ & $\mathrm{n} / \mathrm{a}$ & $40-530$ & $\mathrm{n} / \mathrm{a}$ & $\mathrm{n} / \mathrm{a}$ \\
\hline
\end{tabular}

$\mathrm{n} / \mathrm{a}$ - not available, generally because the leachate was at equilibrium status within 3 yrs and would therefore be below the $\mathrm{C}_{0}$ value. $\mathrm{Ba}$, Se and fluoride were not modelled. 
Table 2. Percentage distribution of specific elements in waste fractions.

\begin{tabular}{|c|c|c|c|c|c|c|c|c|c|c|}
\hline Element & As & $\mathrm{Cd}$ & $\mathrm{Cl}$ & $\mathrm{Cr}$ & $\mathrm{Cu}$ & $\mathrm{F}$ & $\mathrm{Pb}$ & $\mathrm{Hg}$ & $\mathrm{Ni}$ & $\mathrm{Zn}$ \\
\hline Paper and card & 5.9 & 4.9 & 8.5 & 2.4 & 0. & 21.2 & 1.8 & 5.3 & 4.1 & 1.9 \\
\hline Plastic film & 2.0 & 2.5 & 3.7 & 2.8 & 0.1 & 3.0 & 8.6 & 1.1 & 0.6 & 1.0 \\
\hline Dense plastic & 1.4 & 39.9 & 44.3 & 5.3 & 20.7 & 14.9 & 9.6 & 1.4 & 5.7 & 14.0 \\
\hline Textiles & 0.5 & 0.4 & 0.4 & 0.3 & 0.8 & 1.2 & 0.10 & 0.4 & 0.8 & 1.0 \\
\hline $\begin{array}{l}\text { Absorbent hygiene } \\
\text { products }\end{array}$ & 0.2 & 1.3 & 1.2 & 0.3 & 0.2 & 9.8 & 0.6 & 0.3 & 0.3 & 0.5 \\
\hline Wood & 0.9 & 0.2 & 0.2 & 0.5 & 0.0 & 0.0 & 0.5 & 0.0 & 1.2 & 0.2 \\
\hline Combustibles & 14.6 & 8.7 & 21.3 & 16.9 & 1.1 & 6.9 & 6.3 & 2.6 & 4.4 & 15.7 \\
\hline Non-combustibles & 18.1 & 7.7 & 2.6 & 6.5 & 0.3 & 23.7 & 20.4 & 2.0 & 9.2 & 4.2 \\
\hline Organic & 13.3 & 2.9 & 11.6 & 2.1 & 0.6 & 13.4 & 2.4 & 6.5 & 6.2 & 2.0 \\
\hline Ferrous metal & 29.9 & 19.7 & 0.0 & 47.7 & 1.9 & 0.0 & 14.7 & 77.6 & 23.6 & 8.3 \\
\hline Non-ferrous metal & 0.7 & 3.4 & 0.0 & 1.1 & 20.8 & 0.0 & 7.3 & 1.0 & 11.6 & 13.6 \\
\hline Fine material $<10 \mathrm{~mm}$ & 11.4 & 1.1 & 1.2 & 2.1 & 0.3 & 3.4 & 5.9 & 1.9 & 2.6 & 1.5 \\
\hline $\begin{array}{l}\text { Waste electrical \& } \\
\text { electronic equipment }\end{array}$ & 0.0 & 0.0 & 5.0 & 10.1 & 6.8 & 2.6 & 5.9 & 0.0 & 7.7 & 6.1 \\
\hline $\begin{array}{l}\text { Hazardous } \\
\text { household waste } \\
\text { including batteries }\end{array}$ & 1.2 & 7.2 & 0.0 & 2.0 & 45.7 & 0.0 & 15.9 & 0.0 & 22.0 & 30.0 \\
\hline Batteries & 0.3 & 1.3 & 0.0 & 0.3 & 16.3 & 0.0 & 5.0 & 0.0 & 5.4 & 8.0 \\
\hline Clinical waste & 0.4 & 0.1 & 0.1 & 0.1 & 0.0 & 0.6 & 0.6 & 0.2 & 0.2 & 0.1 \\
\hline Paint/varnish & 0.3 & 0.1 & 0.5 & 0.2 & 0.0 & 0.1 & 0.2 & 0.3 & 0.1 & 0.3 \\
\hline Oil & 0.2 & 0.1 & 0.3 & 0.1 & 0.0 & 0.1 & 0.1 & 0.2 & 0.1 & 0.2 \\
\hline $\begin{array}{l}\text { Garden herbicides \& } \\
\text { pesticides }\end{array}$ & 0.3 & 0.1 & 0.5 & 0.2 & 0.0 & 0.1 & 0.2 & 0.3 & 0.1 & 0.3 \\
\hline
\end{tabular}

Note 1 - values in bold represent greater than $10 \%$ of the total contribution of each element.

Note 2 - Columns sum to $100 \%$ down to specific hazardous household waste. [18] 